\title{
REVIEWS
}

\section{The State Hermitage Museum (ed.): Brush and Qalam: 200 years of the collection of the Institute of Oriental manuscripts. Exhibition catalogue.}

St. Petersburg: The State Hermitage Publishers, 2018. 320 S. ISBN ISBN 978-5-93572-824-3

More than 115.000 manuscripts and old prints in 65 different, living and dead, languages belong today to the collection of the Institute of Oriental Manuscripts (Russian Academy of Sciences) in St. Petersburg. On November 27-29, 2018, the 200th anniversary of the foundation of the Asiatic Museum - the Institute of Oriental Manuscripts of the Russian Academy of Sciences was celebrated. On this occasion, the IOM, RAS held the International Forum 'Russia and the Orient. To the 200th Anniversary of the Russian Academic Oriental Studies'. At the same time, on the evening of the first day of this event, the opening ceremony for the exhibition "Brush and Qalam: 200 years of the collection of the Institute of Oriental manuscripts" in the presence of the director of the State Hermitage, Mikhail Piotrovsky, and the director of the Institute of Oriental Manuscripts (RAS), Irina Popova, took place. The research of the history and the cultural heritage of the countries and the peoples of the Orient by the means of their written sources were in the focus of the Asiatic Museum since the first days of its foundation. In this context, a collection of 700 Muslim manuscripts bought from the French consul in Aleppo and Tripoli, J.L. Rousseau, a relative of the famous philosopher Jean-Jacques Rousseau, on the decision of the Russian Academy of Sciences (RAS) in November 1818, played an important role and finally led

(C) Simone-Christiane Raschmann, The Guttingen Academy of Sciences and Humanities 
to the formation of a new department within the RAS - the Asiatic Museum (AM), which later was transformed into the Institute of Oriental Studies (IOS). ${ }^{1}$ On June 19, 2007, the Presidium of the Academy of Sciences ordered to reorganize the St. Petersburg Branch of the Institute of Oriental Studies into the independent Institute of Oriental Manuscripts. ${ }^{2}$

The book under review is the catalogue of the exhibition "Brush and Qalam: 200 years of the collection of the Institute of Oriental manuscripts", which lasted from October 27, 2018 to February 24, 2019 in the State Hermitage, St. Petersburg. Among the 200 objects which were on display in five halls (No. 393-397) on the top floor of the Winter Palace there were not only precious manuscripts and woodblock printed texts as examples for the book culture of the peoples of the Orient in the course of the last two millennia. The scope of the exhibition was broadened by material objects which are closely related to the manuscript culture on one hand (book covers, brushes, kalams, cases for them, ink and woodblocks), and objects used in religious practices along with them (icons, crosses, church plate), and further on articles of clothing, fragments of murals which show parallels in their decoration and/or present the cultural context of the period and region, or, like in the case of coins, are associated with the donors or owners of the manuscripts and block prints. These artefacts of material culture belong to the stocks of the State Hermitage. The curator of the exhibition was Anton Dmitriyevich Pritula, Candidate of Philological Sciences, leading researcher in the State Hermitage's Sector of Byzantium and the Middle East. The impressive exhibition was organized with support of LVMH Moet Hennessy Louis Vuitton.

The scholarly, rich illustrated catalogue, issued by the State Hermitage Publishing House, has a spectacular design created by D.G. Gaskevich. By opening a three-part beautifully decorated book case with details taken from three different manuscripts the reader finds inside attached two volumes with an almost unique number of pages. The first volume of normal book type consists of 360 numbered pages. The scholarly editors and compilers of the catalogue and also the authors of the concept are Irina Popova, Anton Pritula and Natalia Yampolskaya. Three introductory texts written by Mikhail

\footnotetext{
${ }^{1} \mathrm{http}: / / \mathrm{www}$. orientalstudies.ru/eng/index.php?option=com_content\&task=view\&i $\mathrm{d}=46 \&$ Itemid $=82$.

${ }^{2}$ For a more detailled information concerning the history of the Asiatic Museum - the Institute of Oriental manuscripts see now: I.F. Popova (ed.): Asiatic Museum - Institute of oriental Manuscripts, RAS. Collections and Personalia. Moscow: Nauka, Vostochnaia Literatura, 2018.
} 
Piotrovsky, General Director of the State Hermitage, who presents his ideas concerning the poetics of the Oriental manuscripts, by Irina F. Popova who gives an insight in the way from the Asiatic Museum to the Institute of Oriental Manuscripts and by the creators of the exhibition open the volume. The structure of the exhibition catalogue follows the structure of the exhibition itself. "For the sake of convenience, exhibits are grouped into three big sections, each one concerned with a big region characterised by the unity of culture and history: 1) Near East and Middle East; 2) India and Central Asia; 3) Far East. Largely formal, this separation is linked not so much to geography as to the spread and movement of cultures". It goes without saying that these three big sections are to be split into sub-sections. For the convenience of the readers specialized scholars present an introduction into the book culture of these sub-sections ahead their detailed description of each single object on display. In addition, an editorial opens every big section. The author of the editorial of section I: Near and Middle East, A.D. Pritula, writes on the books of the Abrahamic religions: codices and scrolls, written with a kalam (pp. 23-27). For section II: India and Central Asia N.V. Yampolskaya has chosen the topic "Gold on palm leaves: the book traditions of India and Central Asia" for her editorial (pp. 193-195). Section III: Far East starts with an editorial by I.F. Popova on the manuscript and book traditions of the Far East (pp. 281-285). The great variety of book cultures is illustrated by the high number of sub-sections:

I. Hebrew (S.M. Iakerson) pp. 28-31, Syriac (A.D. Pritula) pp. 40-43, Armenian (N.S. Smelova) pp. 52-55, Grusinian (N.S. Smelova) pp. 64-67, Coptic (A.L. Khosroev) pp. 80-81, Ethiopian (E.V. Gusarova) pp. 86-91, Arabic (N.I. Serikov, S.A. Frantsouzoff) pp. 102-105, Persian (O.A. Vodneva) pp. 120-123, Afghan (O.A. Vodneva) pp. 160-161, book culture of Turkic-speaking peoples in the Middle and Minor Asia (O.V. Vasilyeva) pp. 164-169;

II. Indian (E.V. Tanonova) pp. 196-199, book culture of the oasis states in Eastern Turkestan (O.V. Lundysheva) pp. 204-207, Tibetan (A.V. Zorin) pp. 232-235, Mongolian (A.A. Sizova) pp. 248-251, K.M. Bogdanov (Tangut) pp. 263-267;

III. Chinese (I.F. Popova) pp. 286-289, Manchu (T.A. Pang) pp. 314-317, Japanese (K.G. Maranjian) p. 324-327, Korean (A.A. Gureva) pp. 334337.

\footnotetext{
${ }^{3}$ Infra, vol. 1, p. 359.
} 
Not a small number of objects were selected by the curators for a presentation to the public for the first time, like catalogue no. 43, an Ethiopian psalter in the liturgical language of the Ethiopian church Ge'ez from 1878, catalogue no. 113, two wooden tablets with dhāraṇī (Sanskrit in Brāhmī script) from the findings of M.M. Berezovsky's expedition to Kucha (1905-1908) and catalogue no. 170, the table of a Chinese scholar's room from the Qing dynasty. Under the title "The treasures of a Chinese scholar's cabinet", referring to the Wenfang sipu 文房四譜 "Four treasures to the scholar's study" by Su Yijian 蘇易簡 (957-995), M.L. Men'shikova presents a full-page introduction to the catalogue numbers 170-184, a series of items of a scholar's cabinet. Within the scope of this review, only one example for these so far unpublished objects from every big section was given here. The addition of titles, inscriptions and quotations in the original language and script in a large number of object's descriptions throughout all big sections of the catalogue should be highlighted here. As far as the author of the review on hand, who is a specialist of Central Asian manuscripts, and Old Uyghur in particular, can judge, only minor mistakes or inaccuracies are to be found in the bulk of descriptions which have no impact on the high quality of the exhibition catalogue. An index of used abbreviations, a bibliography of the quoted literature and a short English summary complete the volume. The language of the exhibition catalogue is Russian.

The second volume has a format that is known from safina-shaped manuscripts, i.e. an oblong format bound on the top of the folia with text lines running horizontal to the spine. This format is used also for "notepad" purposes and tear-off calendars. This second volume consists of 360 unnumbered pages which present details of the manuscripts and block prints on display with reference to the descriptions in the first volume. The plates allow fascinating and unique insights into details with regard to the calligraphy or illustration of selected items. Details from the St. Petersburg Muraqqa album of Iranian and Indian miniatures that is included in the UNESCO list of world cultural heritage form the beginning and the end of this volume. The unique format of the second volume allows an easy handling side by side with the first volume. Catalogue numbers in brackets added to the captions of the detailed images in this volume serve as a cross reference to the description of the object in the first volume. Headlines guide the viewer through the different sections of presentation.

The catalogue did not only enable the visitors of the exhibition to get a detailed insight on what they saw on display, to learn and understand the his- 
torical and cultural background of the compilation of the texts, the production of the copies, the various and sometimes striking different book cultures. It also gives a deep insight in the richness and diversity of the collection of the Institute of Oriental Manuscripts, which, besides those of the British Library and the Bibliothèque nationale de France, belongs to the largest collections of Oriental manuscripts in the world. The study of this precious exhibition catalogue is therefore also highly recommended to those specialists and interested individuals of Oriental manuscripts which were not able to visit the exhibition "Brush and Qalam" during its comparatively short period of duration.

The exhibition, as well as the published catalogue, greatly benefited from the broad support of those, who are employed in various departments of the State Hermitage and the Institute of Oriental manuscripts. With regard to the excellent illustrations accompanying the scholarly texts I would especially like to refer to the team of the photographers, and the restoration team, who did a huge work in order to restore and prepare the selection of objects for their presentation.

Dr. Simone-Christiane Raschmann Akademie der Wissenschaften zu Göttingen Katalogisierung der Orientalischen Handschriften in Deutschland 